\title{
Redactioneel
}

\section{Toezicht in het sociaal domein: waar staan} we?

Arnt Mein*

Dit nummer van het Tijdschrift voor Toezicht staat in het teken van het toezicht in het sociaal domein. Het begrip sociaal domein wordt gebruikt om het geheel aan gemeentelijke werkzaamheden te omschrijven op het gebied van onder meer werk en inkomen, zorg en ondersteuning en jeugdhulp. Meer concreet gaat het dan om de uitvoering van de Participatiewet, de Wet maatschappelijke ondersteuning 2015 (Wmo 2015) en de Jeugdwet.

Het sociaal domein maakt sinds 2015 een ingrijpende transformatie door. Waar gemeenten van oudsher al waren belast met de uitvoering van de Participatiewet en de Wmo 2015, zijn zij sinds enige tijd ook belast met het toezicht op de naleving van de Wmo 2015. Tegelijkertijd werd het verplichtingen- en sanctieregime van de Participatiewet aangescherpt en moet voor het toezicht in het kader van de Jeugdwet worden samengewerkt met de Inspectie Gezondheidszorg en Jeugd (IGJ). Aldus werden gemeenten geacht hun inwoners sneller en beter te ondersteunen, zodat zij naar vermogen kunnen participeren in de lokale gemeenschap. In het kader van de transformatie werden gemeenten dus geconfronteerd met deels nieuwe en deels angescherpte taken, in het bijzonder op het gebied van het toezicht. Wat betekende dat voor gemeenten, hoe hebben zij daar vorm en inhoud aan gegeven? Eerst moesten zij beleid en regelgeving opstellen en hun organisatie op orde brengen. Maar hoe gaan de toezichthouders (en opsporingsambtenaren) inmiddels te werk? Door welke principes laten zij zich leiden? Welke lessen hebben zij geleerd: wat gaat goed en wat kan beter?

Mr. dr. A.G. Mein is lector Legal Management aan de Hogeschool van Amsterdam, faculteit Maatschappij en Recht en redactielid van Tijdschrift voor Toezicht.
Een onderwerp dat wat minder vanzelfsprekend in de belangstelling lijkt te staan in de toezichtliteratuur, maar dat niettemin van belang is. Want ook op dit beleidsterrein spelen complexe vraagstukken op het gebied van doelmatigheid en doeltreffendheid van het toezicht. Weten gemeenten bijvoorbeeld (de beoogde) samenhang te brengen in het toezicht op basis van de verschillende wetten? Lukt het de verschillende gemeentelijke organisatieonderdelen om samen te werken en hoe verloopt de samenwerking met de rijksinspectie? Wat levert het toezicht op als het gaat om de naleving van de wet en de kwaliteit van de geleverde zorg en ondersteuning? Wordt er ook serieus gehandhaafd? Verder spelen er ook op dit beleidsterrein de nodige vraagstukken op het gebied van rechtmatigheid en rechtvaardigheid. Zo kunnen burgers worden geconfronteerd met ingrijpende bevoegdheden (inlichtingenplicht, huisbezoek) of hoge boetes.

Redenen genoeg om eens de schijnwerper te richten op het toezicht in het sociaal domein.

In dat kader geeft Heinrich Winter een overzicht van de staat van het toezicht en de handhaving in het sociaal domein. Hoe is het toezicht geregeld en georganiseerd? Hoe gaat men feitelijk te werk? Hij schetst een beeld van een ingewikkeld speelveld aan actoren, waardoor de uitvoeringspraktijk er in zijn ogen niet eenvoudiger op is geworden.

Vervolgens gaan Chera Kieviet en Foke de Wit in op het toezicht in het kader van de Participatiewet. Zij laten zien hoe de zogenoemde inlichtingenplicht zich heeft ontwikkeld, een kernbepaling uit de wet die een belangrijke rol speelt in het toezicht in het sociaal domein. Het betreft de verplichting van de bijstandsgerechtigde de gemeente te informeren over alles wat van belang kan zijn voor het recht op een uitkering. Kieviet en De Wit maken duidelijk dat deze verplichting stap voor stap 
ingrijpender is geworden, tegen de achtergrond van een repressief toezicht- en handhavingsklimaat.

$\mathrm{Na}$ deze twee academische bijdragen volgen twee bijdragen uit de toezichtpraktijk. Zo beschrijven Nelleke Verdonk van de IGJ en toezichthouders Muzaffer Yuksekyildiz en Gerrie van Gent van respectievelijk de gemeente Rotterdam en Zoetermeer hun ervaringen met het zoeken van samenwerking bij het houden van toezicht in zogenoemde proeftuinen. Dat blijkt niet mee te vallen, maar samen bereik je meer, aldus de auteurs.

Sanne van der Muijden van het programma Toezicht Sociaal Domein, een samenwerkingsverband van rijksinspecties, en Onno de Zmart van het Verwey-Jonker Instituut schetsen op hun beurt een beeld van een complexe werkelijkheid in het kader van het toezicht in het sociaal domein en houden dan ook een pleidooi voor nieuwe vormen van integraal toezicht. Geen nieuwe grote veranderingen, maar wel verbeteringen stap voor stap.

In een essay breekt Evelien Meester van het expertisecentrum in het sociaal domein Stimulansz een lans voor het brengen van meer samenhang in de handhaving in het sociaal domein. Zo ziet zij integrale handhaving als een goudmijn die nog veel beter kan worden ontgonnen. Handhaving is volgens haar niet alleen een middel om een onterecht verstrekte uitkering of voorziening terug te krijgen, maar ook een schat aan informatie om de kwaliteit van de dienstverlening te verbeteren en misbruik te voorkomen. Die mijn kan worden gedolven door de verschillende gemeentelijke toezichthouders beter te laten samenwerken.

Aansluitend gaat advocaat Matthijs Vermaat in zijn essay in op de rol van vertrouwen bij het beoordelen van de aanvraag om een maatwerkvoorziening op basis van een pgb in het kader van de Wmo. Goede voorlichting en controle vooraf zou handhaving achteraf overbodig moeten maken.

Vervolgens zijn er twee interviems te lezen. Het eerste in het kader van de 'interviewestafette' die de redactie organiseert onder nieuwe bestuurders en leidinggevenden van toezichthouders. Dit keer is, heel passend, de beurt aan Marian Kaljouw en Karina Raaijmakers van de Nederlandse Zorgautoriteit (NZa). Zij bieden een kijkje in de keuken van de zorgautoriteit en gaan in het bijzonder in op de gevolgen van de coronacrisis voor het toezicht in de zorg. Het tweede interview past in een nieuwe serie: in gesprek met een pas gepromoveerde onderzoeker. Paulien de Winter vertelt over haar voor de praktijk van het toezicht in het sociaal domein zeer relevante rechtssociologische onderzoek naar handhaving in de sociale zekerheid bij gemeenten en het Uitvoeringsinstituut Werknemersverzekeringen (UWV). Zij opent naar eigen zeggen de black box van de handhavingspraktijk.

Het themanummer wordt afgesloten met een bespreking, in de vaste serie notenkrakers, van de geruchtmakende uitspraak van de rechtbank Midden-Nederland in de zaak waarnaar in de media ook wel is verwezen als de boodschappenaffaire. Het ging om de terugvordering van een ten onrechte verkregen uitkering omdat betrok- kene gedurende drie jaar wekelijks huishoudelijke boodschappen had ontvangen van haar moeder. Advocaat Anna van Gijssel geeft duiding en plaatst de zaak in perspectief. Al met al een rijk beeld van de stand van het toezicht in het sociaal domein.

Tot slot bespreekt Wilte Zijlstra de hoofdvraag die Cass Sunstein in zijn nieuwe boek Too Much Information - Understanding What You Don't Want to Know stelt: wanneer moet een overheid mensen of bedrijven verplichten informatie te verstrekken? 